agriTECH, 41 (3) 2021, 294-304

\title{
Optimasi Formula Produk Spreadable Gel Berbahan Dasar Biji Selasih Menggunakan Teknik Response Surface Methodology
}

\author{
Formulation of Spreadable Gel Based on Basil Seeds Using Response Surface Methodology Technique \\ Annisa Hayyu Fatmawati*, Dede Robiatul Adawiyah, Nur Wulandari \\ Program Studi Magister Teknologi Pangan, Departemen Ilmu dan Teknologi Pangan, \\ Fakultas Teknologi Pertanian, Institut Pertanian Bogor, Kampus IPB Darmaga, Bogor 16680, Indonesia \\ *Penulis korespondensi: Annisa Hayyu Fatmawati, Email: annisahayyufatmawati@gmail.com
}

Tanggal submisi: 2 Mei 2020; Tanggal revisi: 5 Juli 2020; Tanggal penerimaan: 17 Juli 2020

\begin{abstract}
ABSTRAK
Biji selasih kering diketahui mengandung komponen hidrokoloid yaitu xylan dan glukomanan sehingga memiliki kemampuan membentuk gel bila dicampurkan dengan air. Salah satu pengembangan produk pangan yang dapat memanfaatkan biji selasih sebagai hidrokoloid adalah spreadable gel. Istilah spreadable gel merujuk pada produk selai yang sering digunakan sebagai bahan pengisi atau pelapis produk bakery. Perbedaan spreadable gel dengan selai adalah pada ingredient buah yang diganti dengan biji selasih. Penelitian ini dilakukan dengan rancangan D-Optimal Custom Design menggunakan metode Response Surface Methodology (RSM) secara eksperimental di laboratorium. Tujuan penelitian adalah menetapkan formulasi optimum produk spreadable gel yang memiliki nilai sineresis rendah dan dapat diterima oleh panelis. Penelitian ini menggunakan variabel bebas rasio biji selasih kering $(\mathrm{g})$ :air $(\mathrm{mL})(1: 10-1: 30)$, lama perendaman (30-90 menit), penambahan gula (30-50\%), rentang pH (4$5)$, variasi perisa (leci dan jeruk), dan konsentrasi perisa $(0,05 \% ; 0,1 \% ; 0,2 \%)$. Melalui optimasi diperoleh hasil yaitu spreadable gel biji selasih terbaik dengan formulasi rasio biji selasih kering $(\mathrm{g})$ terhadap air $(\mathrm{mL}) 1: 10$, penambahan gula $30 \%$, lama perendaman 48 menit, dan $\mathrm{pH} 5$ dengan penambahan perisa jeruk $0,1 \%$ yang menghasilkan nilai viskositas maksimum $24800 \mathrm{cP}$ yaitu mudah dioles pada roti, tingkat sineresis $\pm 3 \%$ dan nilai sensori tingkat kesukaan pada angka rerata 6,39 skala suka.
\end{abstract}

Kata kunci: Biji selasih; selai selasih; daya oles; spreadable gel; viskositas

\begin{abstract}
Dried basil seed contains hydrocolloid components such as xylan and glucomannan; hence, it forms a gel immediately after hydration. Meanwhile, one of the developed food products suitable for basil seeds as hydrocolloids is spreadable gel. This term refers to jam products often used as filler or coating in bakery products. The difference between spreadable gel and jam is the fruit ingredient used in place of basil seeds. This experimental study was conducted using D-Optimal Custom Design with Response Surface Methodology (RSM). The study aimed to determine the optimum formulation of a spreadable gel with a low syneresis value and acceptable to panelists. Furthermore, the independent variables include ratio of dried basil seeds $(\mathrm{g})$ :water $(\mathrm{mL})(1: 10-1: 30)$, soaking time (30-90 $\mathrm{min})$, sugar addition (30-50\%), pH range (4-5), flavor variation (lychees and oranges), and flavor concentrations $(0.05 \% ; 0.1 \% ; 0.2 \%)$. Based on the results, the best spreadable gel was obtained from the ratio of dry basil seeds $(\mathrm{g})$ to water $(\mathrm{mL}) 1: 10,30 \%$ sugar, 48 min soaking time, and $\mathrm{pH} 5$ with $0.1 \%$ orange flavor which produced a maximum viscosity value of $24800 \mathrm{cP}$ indicating easy spreadability on bread, syneresis level of $\pm 3 \%$, and average preference level of 6.39 .
\end{abstract}

Keywords: Basil seeds; jam basil seeds; spreadability; spreadable gel; viscosity 


\section{PENDAHULUAN}

Pangan olahan berbentuk jelly dan selai membutuhkan bahan pengental yang dikenal dengan gelling agent. Bahan pengental yang biasa digunakan untuk pangan olahan baik industri maupun rumah tangga berupa senyawa yang bersifat hidrokoloid yaitu $\mathrm{Na}$ alginat, $\mathrm{Na}$ Carboxymethyl cellulose (CMC), pektin, dan karagenan. Namun, bahan mentah untuk pembuatan senyawa hidrokoloid tersebut kebanyakan masih harus diimpor dari luar negeri. Alternatif bahan mentah untuk menghasilkan senyawa hidrokoloid dapat berasal dari tanaman, salah satunya tanaman basil. Tanaman tersebut berupa semak dan di Indonesia dikenal dengan nama tanaman selasih (Ocimum basilicum L.). Salah satu bagian dari tanaman selasih yang dapat dimanfaatkan sebagai pangan adalah bijinya yang memiliki morfologi kecil, bulat panjang, saat masih muda berwarna putih dan setelah tua menjadi keras berwarna cokelat atau hitam dan mengembang membentuk gel bila kontak dengan air. Biji selasih jika kontak dengan air, bagian luar epidermis akan pecah dan mengeluarkan filamen gel yang segera menyerap air dan membentuk lapisan gel yang tampak seperti kapsul transparan (Razavi dkk., 2009). Produksi lapisan gel yang bersifat hidrofilik ini merupakan bentuk dari adaptasi bagian pericarp biji selama proses hidrasi. Proses adaptasi ini disebut myxodiaspory dan umum terjadi pada biji tertutup atau angiospermae (Zhou, 2012). Selaput transparan atau gel yang terbentuk ini penyusun utamanya adalah pektin dan hemiselulosa yang akan terus mengalami pengembangan selama hidrasi. Karakteristik fisik biji selasih berupa kemampuan membentuk gel dapat berpotensi untuk digunakan sebagai hidrokoloid pengental, penstabil, pengemulsi, fat replacer ataupun pembentuk edible coating.

Penggunaan biji selasih sebagai bahan pangan umum dijumpai pada minuman. Biji selasih mempunyai kandungan gizi makro yang cukup tinggi diantaranya karbohirat 48\%, lemak 4\%, dan protein $23 \%$ (Bucktowar dkk., 2016). Penyusun karbohidrat dalam biji selasih yang utama terdiri dari glukomanan (43\%), xilan (24.3\%), dan glukan (2.31\%) (Razavi, 2017). Ekstraksi gel dari biji selasih menghasilkan polisakarida dengan dua komponen utama yaitu glukomanan (43\%) yang bersifat hidrofobik dan xilan (24,29\%) yang bersifat hidrofilik. Xilan yang bersifat hidrofilik tersebut berperan menyerap air dan menyebabkan biji selasih mengembang membentuk gel (Hosseini-Parvar dkk., 2010). Galaktomanan dan glukomanan merupakan kategori penting polisakarida non-pati yang berasal dari tanaman (Brodkorb dkk., 2019). Polisakarida non pati tersebut memiliki sifat kimia dan molekul yang berbeda- beda sehingga menghasilkan hidrokoloid atau gel yang dapat diaplikasikan pada olahan makanan dengan meningkatkan tekstur dan organoleptik makanan (Razavi dkk., 2009). Gel biji selasih merupakan hidrokoloid nabati dengan berat molekul sebesar $2320 \mathrm{kDa}$ dan memiliki nilai fungsional yang dapat dibandingkan dengan gel komersial lainnya. Selain itu biji selasih memiliki harga yang lebih murah, mudah ditemukan, kelarutan lebih tinggi, serta mengandung komponen hidrofilik yang mampu menyerap air dan mengembang hingga 20x lebih besar dari bahan aslinya (Naji-Tabasi dan Razavi, 2017). Berat molekul polisakarida gel biji selasih yang mencapai $2320 \mathrm{kDa}$ akan memberikan ciri khas perilaku kekentalan larutan. Penelitian mekanisme pembentukan gel menggunakan pengukuran reologi dinamis (NajiTabasi dan Razavi, 2017) melaporkan perilaku aliran gel biji selasih merupakan tipe aliran pseudoplastis (shear thinning), yang termasuk dalam salah satu fluida nonNewtonian. Sifat ini membuat gel biji selasih stabil dalam berbagai proses pengolahan seperti heating, freezing, ionic strength, $\mathrm{pH}$, ataupun adanya penambahan gula. Selain itu, gel biji selasih menunjukkan tekstur lengket dan adhesive sehingga cocok untuk salad dressing ataupun jam yang berpotensi untuk diaplikasikan di industri (Zameni dkk., 2015).

Penelitian dibidang pangan seperti penentuan sifat reologi pada gel biji selasih yang ditambahkan gula (sukrosa, glukosa, fruktosa, dan laktosa) dan garam $\left(\mathrm{NaCl}\right.$ dan $\mathrm{CaCl}_{2}$ ) pernah dilakukan oleh Salehi dan Kashaninejad (2018) dengan hasil bahwa penambahan gula dapat menaikkan kekentalan pada gel selasih dan penambahan garam dapat menurunkan kekentalan gel. Hasil uji reologi menunjukkan bahwa index sifat alir $(n)$ dari gel biji selasih meningkat dengan penambahan sukrosa, glukosa, laktosa, $\mathrm{NaCl}$, dan $\mathrm{CaCl}_{2}$ namun menurun dengan penambahan fruktosa. Berbagai penelitian yang dilakukan pada tanaman selasih khususnya di Indonesia berfokus pada potensi selasih sebagai pestisida dan obat-obatan namun belum banyak dilakukan penelitian mengenai potensi pemanfaatan biji selasih sebagai produk pangan. Selama ini eksplorasi biji chia lebih banyak dilakukan dibanding biji selasih yang juga memiliki karakteristik fisik yang sama, yaitu mengembang ketika dicampur dengan air. Pengembangan produk pangan lain perlu dilakukan melihat potensi biji selasih sebagai gelling agentmisalnya dalam bentuk produk spreadable gel. Istilah spreadable gel merujuk pada produk selai yang biasanya digunakan sebagai bahan pengoles atau bahan pengisi roti (bakery products). Selai umumnya terbuat dari bahan utama bubur buah ditambah pektin, gula, dan asam (Badan Standardisasi Nasional, 2008). Sedangkan spreadable gel akan dibuat menggunakan bahan utama biji selasih 
terhidrasi. Berdasarkan informasi ilmiah tersebut maka perlu dilakukan penelitian mengenai pengembangan produk spreadable gel berbasis biji selasih. Penelitian ini bertujuan untuk menetapkan formulasi optimum spreadable gel yang memiliki sineresis rendah dan dapat diterima oleh panelis.

\section{METODE PENELITIAN}

\section{Alat dan Bahan}

Alat-alat yang digunakan dalam penelitian ini adalah analytical balance (Metler Toledo model AB104-S/FACT, Switzerland) untuk menimbang, moisture analyzer infrared (AND model ML-50, Japan) untuk analisis kadar air, viscometer (Brookfield model DV1MLVTJ10, USA) untuk analisis viskositas, $\mathrm{pH}$ meter (Metro Ohm model 913, Switzerland) untuk analisis nilai $\mathrm{pH}$, hand refractometer (Atago model MASTER 93- $\mathrm{H}$, Japan) untuk analisis total padatan terlarut, $\mathrm{a}_{w}$ analyzer (Novasina model NV260-0179, Switzerland) untuk analisis $a_{w}$ atau aktivitas air, oven (Memmert model UN 55, Germany), desikator (Duran model DIN 12491, Germany), cawan porselen, tanur, labu Kjeldahl, Erlenmeyer $125 \mathrm{~mL}$ (Pyrex), labu Soxhlet, kertas saring, kapas analisis kadar lemak, alat destilasi, panci keramik, kompor gas (Rinai), dan peralatan uji organoleptik. Bahan-bahan yang digunakan dalam penelitian ini terdiri dari biji selasih kering dengan karakteristik biji berwarna coklat tua hingga hitam, berbentuk bulat kecil dan tekstur keras yang diperoleh dari pasar lokal Jakarta, air, asam sitrat food grade, gula sukrosa, perisa leci, perisa jeruk, $\mathrm{H}_{2} \mathrm{SO}_{4} \mathrm{pa}$, $\mathrm{NaOH} 30-33 \%, \mathrm{H}_{3} \mathrm{BO}_{3} 3 \%$, $\mathrm{HCl} 0,1 \mathrm{M}$, larutan bromcresol green, akuades, indikator metil merah (trayek pH 4,2- 6,2), dan heksana.

\section{Tahapan Penelitian}

Penelitian ini terdiri dari tiga tahapan yaitu: 1) karakterisasi kimia biji selasih kering, 2) formulasi awal spreadable gel biji selasih, dan 3) formulasi akhir spreadable gel biji selasih.

\section{Karakterisasi Kimia Biji Selasih Kering}

Sampel berupa biji selasih kering dibeli dari pasar lokal Jakarta (Indonesia) dengan karakteristik biji berwana hitam, bentuk bulat kecil dan tekstur keras. Sampel dipilih dengan penampakan biji yang sama kemudian disortir dari pengotor secara visual. Biji selasih kering dilakukan karakterisasi kimia yaitu analisis proksimat sebelum digunakan sebagai bahan baku spreadable gel. Analisis proksimat terdiri dari kadar air wet basis (Moisture analyzer AND ML-50), kadar lemak, kadar protein, kadar abu menggunakan metode Horwitz dan AOAC International (2006), dan kadar karbohidrat (by difference).

\section{Formulasi Awal Spreadable Gel Biji Selasih}

Formulasi awal gel oles dibuat dengan variabel tetap yaitu suhu ruang dan variabel bebas yaitu rasio biji selasih kering : air ( $\mathrm{g}: \mathrm{mL})$, lama perendaman (menit), penambahan gula (\%), dan rentang $\mathrm{pH}$ dengan pemberian asam sitrat food grade. Penentuan nilai kisaran variabel dalam formulasi awal diperoleh melalui studi literatur terhadap produk yang sejenis (Ramadhan dan Trilaksani, 2017) dan dari hasil pengamatan subjektif pada saat trial and error. Nilai variabel yang digunakan adalah rasio biji selasih kering:air (1:10 -1:30), lama perendaman (30-90 menit), penambahan gula (30-50\%), dan rentang $\mathrm{pH}$ (4-5). Nilai kisaran variabel tersebut kemudian diolah dengan perangkat lunak Design Expert 11.0 (Trial version) yang diproduksi oleh Stat-ease Minneapolis USA. Perangkat lunak ini merupakan perangkat statistik yang khusus digunakan untuk membuat rancangan percobaan. Rancangan yang digunakan adalah D - Optimal (custom) design dan dilanjutkan dengan Response surface methodology (RSM) untuk optimasi formula dengan 20 kombinasi perlakuan dan tiga kali pengulangan. Masing-masing perlakuan dianalisis nilai respon viskositasnya. Nilai respon viskositas akan digunakan sebagai data utama dimana viskositas merupakan parameter penting pada produk spreadable gel. Proses optimasi formula dipilih dengan nilai desirability tertinggi (mendekati nilai 1 ) berdasarkan penetapan target dan tingkat kepentingan yang diharapkan. Sebelum penentuan formulasi akhir, hasil perolehan optimasi formula pada tahap 2 terlebih dahulu dilakukan verifikasi. Verifikasi bertujuan untuk melakukan pembuktian terhadap prediksi dari nilai respon viskositas hasil optimasi yang diberikan oleh program Design Expert 11.0. Nilai respon viskositas aktual akan didapatkan dari verifikasi yang kemudian dibandingkan dengan prediksi respon yang diberikan oleh Design Expert 11.0.

\section{Formulasi Akhir Spreadable Gel Biji Selasih}

Pada tahap ketiga ini dilakukan formulasi akhir spreadable gel serta pengukuran sifat fisikokimia (nilai aktivitas air atau $\mathrm{a}_{\mathrm{w}^{\prime}} \mathrm{pH}$, sineresis, dan total padatan terlarut) kemudian dilanjutkan uji sensori hedonik. Formulasi akhir spreadable gel dibuat menggunakan formula hasil optimasi dan verifikasi tahap sebelumnya kemudian ditambahkan variabel jenis perisa yaitu leci dan jeruk, masing-masing tiga taraf konsentrasi $(0,05 \% ; 0,1 \% ; 0,2 \%)$. Spreadable gel ini dibuat 
tanpa ada tambahan warna. Rasa leci dan jeruk dipilih sebagai perisa yang paling cocok dengan kenampakan produk spreadable gel biji selasih. Produk spreadable gel pada tahap 3 dibuat dengan cara memanaskan biji selasih terhidrasi yang sudah dicampurkan dengan gula dan asam hingga suhu $80^{\circ} \mathrm{C}$, kemudian menambahkan perisa. Adonan dihomogenisasi selama 1,5 menit sambil diaduk hingga teksturnya semi padat lalu angkat dan dikemas.

\section{Prosedur Analisis}

\section{Analisis proksimat}

Analisis proksimat terdiri dari kadar lemak metode Soxhlet (AOAC 920.39), kadar protein metode Kjeldahl (AOAC 978.04) serta kadar abu (AOAC 930.05) menggunakan metode Horwitz dan AOAC International (2006), kadar air wet basis menggunakan moisture analyzer infrared (AND model ML-50, Japan) dengan suhu $105{ }^{\circ} \mathrm{C}$ selama 47 menit, dan kadar karbohidrat menggunakan metode by difference.

\section{Analisis viskositas spreadable gel biji selasih}

Viskositas produk spreadable gel diukur dengan adaptasi metode Segura-Campos dkk. (2014) menggunakan viskometer (Brookfield model DV1MLVTJ10, USA). Sampel diukur menggunakan spindle 5 dengan kecepatan $60 \mathrm{rpm}$ pada suhu ruang. Waktu kesetimbangan pembacaan adalah 30 detik.

\section{Analisis water activity $\left(\mathrm{a}_{\mathrm{w}}\right)$}

Pengukuran $a_{w}$ spreadable gel dilakukan menggunakan $\mathrm{a}_{\mathrm{w}}$ analyzer Novasina model NV2600179, Switzerland. Instrumen dinyalakan terlebih dahulu kemudian tunggu sampai tampilan warming up pada display tertera selesai. Sampel diletakkan pada cawan pengukuran, sejumlah sampai batas yang ada pada cawan. $\mathrm{A}_{\mathrm{w}}$ analyzer dibuka kemudian cawan ditempatkan pada analyzer dan dilakukan pembacaan.

\section{Analisis sineresis (AOAC, 2005)}

Sineresis menunjukkan jumlah air yang keluar dari gel setelah sampel gel oles berbasis biji selasih yang dikemas dalam kemasan plastik bertutup disimpan pada suhu refrigerator $\left(7^{\circ} \mathrm{C}\right)$ selama 72 jam, diikuti penyimpanan pada suhu ruang selama 24 jam. Sineresis dihitung dengan mengukur jumlah air yang keluar dari produk setelah produk disimpan dibandingkan dengan berat awal produk sebelum disimpan. Perhitungan tingkat sineresis termuat pada Persamaan 1.
Sin erkis $=\frac{C-B}{A} \times 100 \%$

Dimana $A=$ bobot awal sampel sebelum penyimpanan (g), B = bobot plastik sebelum penyimpanan $(\mathrm{g})$, dan $\mathrm{C}$ = bobot plastik + air setelah penyimpanan $(\mathrm{g})$.

\section{Uji sensori hedonik (Meilgaard dkk., 2007)}

Produk dengan nilai viskositas tertinggi akan digunakan pada uji hedonik. Keseragaman (homogen) produk spreadable gel yang digunakan uji hedonik didasarkan pada visualisasi. Spreadable gel akan dioleskan pada sebuah plate kaca bening berukuran $10 \times 10 \mathrm{~cm}$, produk yang homogen ditunjukkan dengan tidak adanya biji yang belum terhidrasi. Uji hedonik dilakukan berdasarkan pengujian rasa dan kesukaan keseluruhan produk. Masing-masing parameter diberi skala angka dari skala 1 (sangat tidak suka), 2 (tidak suka), 3 (sedikit suka), 4 (agak suka), 5 (tepat suka), 6 (sangat suka), dan skala 7 (sangat suka sekali). Penilaian dilakukan oleh 38 panelis dengan rentang usia 19-40 tahun. Pemilihan panelis berdasarkan segmentasi demografis yaitu rentang usia dan bertempat tinggal di kota sehingga panelis terbiasa mengonsumsi roti dan selai. Selai merupakan produk yang disukai semua orang sehingga untuk segmentasinya tidak dibatasi.

Setiap panelis diberi gelas plastik yang diisi dengan sampel yang diberi kode menggunakan tiga angka acak. Sebelum pengujian, seluruh panelis diberi instruksi lisan tentang arah pengujian dan atribut sensori yang diujikan yaitu rasa, daya oles, dan kesukaan pada keseluruhan produk. Panelis juga diberi pembersih langit-langit mulut (air mineral), sepotong roti untuk uji daya oles, dan juga lembar penilaian.

Daya oles adalah kemampuan selai atau produk gel untuk dioleskan secara merata pada roti. Daya oles merupakan parameter yang spesifik pada produk spreadable gel dan dapat digunakan sebagai penentu mutunya. Seperti halnya selai, spreadable gel yang baik adalah mudah dioleskan pada roti dan tidak menggumpal. Spreadable gel yang bertekstur keras atau terlalu encer akan sulit dioleskan secara merata pada roti. Roti yang digunakan untuk pengujian daya oles adalah jenis roti tawar dengan ukuran $12 \mathrm{~cm} \times 11,5$ $\mathrm{cm} \times 12 \mathrm{~mm}(\mathrm{p} \times \mid \times \mathrm{t})$. Panelis diberi alat pengoles berupa sendok pipih dan sampel sebanyak $10 \mathrm{~g}$ untuk masing-masing sampel. Sampel tersebut diletakkan di atas roti dan panelis diminta untuk mengoleskannya. Penilaian kemudahan daya oles menggunakan skala 1 (tidak mudah sekali), 2 (tidak mudah), 3 (sedikit mudah), 4 (agak mudah), 5 (tepat mudah), 6 (sangat mudah), dan skala 7 (sangat mudah sekali). 


\section{Analisis Data}

Data hasil analisis proksimat dianalisis secara deskriptif kualitatif. Formula gel biji selasih dianalisis dengan menggunakan metode Response Surface Metodologi (RSM) berikut ANOVA yang ada di program Design Expert 11.0 (Trial version). Hasil uji organoleptik formulasi akhir produk gel oles biji selasih dianalisis menggunakan metode statistik two way ANOVA dan apabila terdapat signifikansi maka dilanjutkan dengan uji DMRT 5\% pada perangkat lunak Microsoft Excel 2013.

\section{HASIL DAN PEMBAHASAN}

\section{Karakteristik Kimia Biji Selasih Kering}

Analisis proksimat memiliki manfaat untuk penilaian kualitas suatu bahan pangan terutama pada standar zat makanan yang seharusnya terkandung di dalamnya. Selain itu, analisis proksimat juga dapat digunakan sebagai pedoman untuk mengevaluasi dan menyusun formula suatu produk pangan (Naji-Tabasi dan Razavi, 2017). Perolehan analisis proksimat biji selasih kering dalam penelitian ini ditunjukkan pada Tabel 1 .

Tabel 1. Hasil analisis proksimat biji selasih kering

\begin{tabular}{cccc}
\hline No & Komponen & Unit & Hasil \\
\hline 1. & Kadar air & $\%$ bb & $9,87 \pm 0,31$ \\
2. & Kadar abu & $\% b k$ & $3,68 \pm 0,20$ \\
3. & Protein & $\% b k$ & $9,77 \pm 0,54$ \\
4. & Lemak & $\% b k$ & $6,59 \pm 0,60$ \\
5. & Karbohidrat & $\% b k$ & $70,09 \pm 0,10$ \\
\hline
\end{tabular}

Keterangan: Data disajikan sebagai rataan \pm standar deviasi

Hasil analisis proksimat biji selasih kering yang digunakan dalam penelitian ini menunjukkan nilai kadar air 9,87 $\pm 0,31 \%$ dimana hasil ini lebih tinggi dari penelitian Munir dkk. (2017) sebesar 9,19\% dan Nazir dkk. (2017) sebesar 9,4\%. Selain karena pengaruh habitat tumbuh dan varietas, hal ini juga kemungkinan adanya perbedaan metode dan lama pengeringan. Namun, kadar air tersebut masih memenuhi syarat untuk penyimpanan biji yaitu maksimum sebesar $10 \%$. Demikian pula untuk kadar karbohidrat $(70,09 \pm 0,10 \%)$ juga menunjukkan kondisi yang sama dengan kadar air, yaitu hasil penelitian ini lebih tinggi dari penelitian Munir dkk. (2017) sebesar 50,9\% dan Nazir dkk. (2017) sebesar 43,9\%. Kadar karbohidrat tinggi kemungkinan dipengaruhi oleh perbedaan ekosistem tempat tumbuh biji selasih dan waktu panen. Penelitian lain menunjukkan bahwa nilai proksimat suatu bahan dapat berbeda karena dipengaruhi oleh kandungan kimia tanah tempat menanam, kondisi cuaca, dan perbedaan perlakuan bercocok tanam (Mathews, 1993). Selain itu, beberapa studi menyebutkan perbedaan ketinggian daratan tempat menanam biji selasih berpengaruh terhadap munculnya variasi nilai proksimat biji selasih. Penyusun karbohidrat dalam biji selasih yang utama terdiri glukomanan (43\%), xylan (24.3\%), dan glukan (2.31\%) (Razavi, 2017). Adanya kandungan xylan membuat biji selasih mampu membentuk gel di dalam air sehingga berpotensi untuk dimanfaatkan sebagai gelling agent. Berbeda dengan kadar air dan karbohidrat, hasil analisis kadar protein $(9,77 \pm 0,54 \%)$ pada penelitian ini menunjukkan nilai lebih rendah dibandingkan penelitian Munir dkk. (2017) sebesar $17,72 \%$ dan Nazir dkk. (2017) sebesar 10\%. Demikian pula kadar lemak juga memberikan hasil lebih rendah $(6,59 \pm 0,60 \%)$ dari penelitian Munir dkk. (2017) sebesar $9,68 \%$ dan sebesar $33 \%$. Biji selasih yang ditanam pada dataran tinggi memiliki kandungan lemak yang lebih tinggi dan protein yang rendah (Ayerza, 2011).

\section{Formulasi Awal Spreadable Gel Biji Selasih}

Setelah dilakukan analisis proksimat pada biji selasih kering, kemudian dilanjutkan pembuatan spreadable gel biji selasih dengan formulasi awal menggunakan 20 perlakuan percobaan berdasarkan rancang percobaan dari D-Optimal (Custom) Design (Tabel 2). Semua formulasi spreadable gel tersebut diukur nilai respon viskositasnya. Data viskositas yang diperoleh kemudian dilakukan perancangan model polinomial yang tepat dalam memprediksi hubungan antara variabel perlakuan dengan respon utama (viskositas) menggunakan Response Surface Methodology (RSM). Model yang dipilih adalah model yang dapat menjelaskan keterkaitan hubungan antara variabel perlakuan dan respon seperti yang diperlihatkan dengan nilai koefisien determinasi yang tinggi $\left(R^{2}\right)$. Nilai $R^{2}$ semakin bagus jika mendekati 1,0 .

Rancangan D-Optimal (Custom) Design menyediakan lima jenis model polinomial untuk membentuk persamaan regresi, yaitu mean, linear, quadratic, special cubic, dan cubic. Salah satu dari model tersebut direkomendasikan oleh program Design Expert 11.0 (Trial version) sebagai model yang paling mewakili respon. Dalam penelitian ini, polinomial yang direkomendasikan adalah quadratic atau kuadratik. Berdasarkan model kuadratik, diperoleh hasil bahwa variabel rasio biji selasih kering:air, lama perendaman, penambahan gula, dan $\mathrm{pH}$ mempunyai keeratan yang tinggi dengan respon viskositas yang ditunjukan dengan nilai koefisien determininasi $\left(R^{2}\right)$ sebesar 0,9956 (Tabel 3). Hal ini menunjukkan bahwa model 
Tabel 2. Formulasi awal dan hasil respon viskositas gel biji selasih

\begin{tabular}{cccccc}
\hline Formula & $\begin{array}{c}\text { Rasio biji selasih kering : air } \\
(\mathrm{g}: \mathrm{mL})\end{array}$ & $\begin{array}{c}\text { Lama perendaman } \\
(\mathrm{menit})\end{array}$ & $\begin{array}{c}\text { Penambahan gula } \\
(\%)\end{array}$ & $\mathrm{pH}$ & $\begin{array}{c}\text { Viskositas } \\
(\mathrm{cP})\end{array}$ \\
\hline 1 & $10: 160$ & 90 & 40 & 4 & 5000 \\
2 & $10: 160$ & 30 & 50 & 4 & 6500 \\
3 & $10: 160$ & 35 & 30 & 4 & 6500 \\
4 & $10: 160$ & 61 & 43 & 5 & 5500 \\
5 & $8: 164$ & 90 & 30 & 5 & 1500 \\
6 & $8: 164$ & 90 & 50 & 4 & 4250 \\
7 & $8: 164$ & 59 & 40 & 5 & 3000 \\
8 & $8: 164$ & 56 & 40 & 5 & 2000 \\
9 & $6: 180$ & 56 & 50 & 4 & 750 \\
10 & $6: 180$ & 86 & 30 & 4 & 750 \\
11 & $6: 180$ & 30 & 34 & 5 & 750 \\
12 & $6: 180$ & 90 & 44 & 5 & 1250 \\
13 & $10: 100$ & 30 & 35 & 5 & 24250 \\
14 & $10: 100$ & 80 & 30 & 4 & 24350 \\
15 & $10: 100$ & 52 & 48 & 4 & 16500 \\
16 & $10: 100$ & 90 & 50 & 5 & 23750 \\
17 & $8: 188$ & 30 & 41 & 4 & 1750 \\
18 & $8: 188$ & 52 & 30 & 5 & 1500 \\
19 & $8: 188$ & 71 & 40 & 4 & 2000 \\
20 & $8: 188$ & 30 & 50 & 5 & 1500 \\
\hline
\end{tabular}

kuadratik sudah sesuai dan mampu menjelaskan dengan baik hubungan antara variabel perlakuan dengan hasil respon (Zhang dkk., 2010).

Tabel 3. Tabel regresi RSM model kuadratik pada respon viskositas gel biji selasih

\begin{tabular}{cc}
\hline Parameter & Nilai \\
\hline Std. Dev. & 2231,79 \\
Mean & 6662,50 \\
C.V. $\%$ & 33,50 \\
$R^{2}$ & 0,9956 \\
Adjusted $\mathrm{R}^{2}$ & 0,9719 \\
\hline
\end{tabular}

Adapun persamaan regresi model kuadratik untuk nilai viskositas gel oles biji selasih adalah:

$$
\begin{aligned}
\text { Viskositas }= & 2857,84-9904,30 A+261,80 B-341,15 C+478,96 \\
& +211,49 A B+1247,10 A C-1528,80 A D+829,68 B C \\
& -2,53 B D+402,18 C D+8366,61 A^{2}+1229,58 B^{2} \\
& +640,59 C^{2}-1810,72 D^{2}
\end{aligned}
$$

Dimana $A=$ Penambahan air, $B=$ Lama perendaman, $C$ = Penambahan gula, dan $D=\mathrm{pH}$.

Persamaan regresi inilah yang dapat menjelaskan besarnya pengaruh dari masing-masing variabel terhadap respon dan sekaligus dapat digunakan untuk memprediksi besarnya nilai respon yang dihasilkan pada kondisi nilai ingredien-ingredien tertentu. Dalam persamaan regresi hasil analisis RSM tersebut terdapat konstanta (angka), koefisien regresi (angka diikuti variabel), variabel (huruf), serta tanda operasi hitung (+) dan (-). Tanda dan besarnya koefisien menunjukkan efek variabel pada respons. Tanda $(+)$ berarti efek sinergis sedangkan tanda (-) berarti efek antagonistik. Koefisien dengan satu huruf $(A, B, C, D)$ mewakili pengaruh variabel tertentu. Koefisien dengan dua huruf $(A B, A C, A D, B C, B D, C D)$ mewakili pengaruh interaksi antar variabel. Sedangkan, koefisien dengan huruf kuadrat $\left(A^{2}, B^{2}, C^{2}, D^{2}\right)$ mewakili efek kuadrat suatu variabel.

Pada koefisien dengan satu huruf, tanda (-) mengindikasikan penurunan respon jika nilai variabel tersebut ditingkatkan. Berdasarkan persamaan regresi pada penelitian ini meningkatkan variabel air $(A)$ dan gula (C) akan menurunkan viskositas gel. Hal ini karena kemungkinan biji selasih kering dan gula saling berkompetisi menyerap air seiring dengan penambahan keduanya. Selain itu, Adanya peningkatan sifat hidrokoloid disebabkan oleh kemampuan biji selasih mengembang dalam air sehingga hidrokoloid membentuk gel dengan kekentalan atau viskositas tertentu. Namun, penambahan jumlah air yang lebih banyak akan membuat gel yang terbentuk semakin 
encer. Ketika memiliki kontak dengan air, biji selasih akan terhidrasi menghasilkan jaringan gel tiga dimensi yang dibentuk melalui proses lilitan dan ikatan silang antar rantai polimer yang ada di hidrokoloid. Pembentukan jaringan ini bergantung pada sifat setiap ikatan antar rantai. Bertambahnya jumlah air akan memperluas dispersi biji selasih sehingga terjadi penurunan viskositas karena jarak antar rantai semakin jauh. Pada koefisien dengan dua huruf, tanda (-) mengindikasikan apabila salah satu nilai variabel ditingkatkan maka variabel yang lain harus diturunkan untuk mendapatkan respon viskositas yang sama. Dalam penelitian ini, interaksi antara penambahan air dan $\mathrm{pH}(A D)$ menunjukkan tanda (-). Pada koefisien dengan huruf kuadrat, tanda $(-)$ mengindikasikan respon minimum di titik pusat grafik sedangkan tanda $(+)$ mengindikasikan respon maksimum di titik pusat grafik.

Setelah penentuan model polinomial, selanjutnya dilakukan pengujian ANOVA untuk melihat signifikansi perbedaan masing-masing variabel terhadap respon pada selang kepercayaan 95\%. Berdasarkan hasil uji ANOVA menunjukkan bahwa faktor yang berpengaruh signifikan terhadap viskositas gel biji selasih adalah rasio biji selasih kering:air $(A)$, interaksi rasio biji selasih kering:air dengan penambahan gula, dan interaksi rasio biji selasih kering:air dengan rentang $\mathrm{pH}(p<0.05)$. Rasio biji selasih kering : air menjadi variabel utama yang paling berpengaruh terhadap nilai respon viskositas gel biji selasih. Pengaruh yang signifikan ini juga diikuti oleh interaksinya dengan variabel lain. Perolehan nilai viskositas tertinggi yaitu $24350 \mathrm{cP}$ pada rasio biji selasih kering:air (1:10), dan nilai viskositas terendah yaitu 750 CP pada rasio biji selasih kering:air (1:30). Samateh dkk. (2018) melaporkan bahwa sifat hidrokoloid biji selasih lebih dipengaruhi adanya penambahan sejumlah air. Sifat hidrokoloid pada biji selasih akan meningkat jika berinteraksi dengan air. Adanya peningkatan sifat hidrokoloid disebabkan oleh kemampuan biji selasih mengembang dalam air sehingga hidrokoloid membentuk gel dengan kekentalan atau viskositas tertentu. Namun, penambahan jumlah air yang lebih banyak akan membuat gel yang terbentuk semakin encer. Ketika memiliki kontak dengan air, biji selasih akan terhidrasi menghasilkan jaringan gel tiga dimensi yang dibentuk melalui proses lilitan dan ikatan silang antar rantai polimer yang ada di hidrokoloid. Pembentukan jaringan ini bergantung pada sifat setiap ikatan antar rantai. Bertambahnya jumlah air akan memperluas dispersi biji selasih sehingga terjadi penurunan viskositas karena jarak antar rantai semakin jauh.

Optimasi formula dilakukan setelah uji ANOVA untuk mendapatkan formula optimal berdasarkan kriteria yang diinginkan dengan pemilihan kepentingan serta tujuan yang dikehendaki terhadap respon serta variabel yang digunakan. Selama ini belum ada standar viskositas yang baik untuk selai ataupun produk pangan oles. Sebagai perbandingan, maka dilakukan pengukuran nilai viskositas beberapa produk selai komersial yang merupakan produk sejenis dengan spreadable gel. Pengukuran tersebut menunjukkan nilai viskositas dengan kisaran 30000-70000 cp. Nilai tersebut lebih tinggi dari semua perolehan data viskositas spreadable gel biji selasih di mana viskositas tertinggi adalah $24350 \mathrm{cp}$. Oleh karena itu, dalam penelitian ini kriteria yang diinginkan adalah nilai viskositas yang semaksimal mungkin.

Ketika kriteria sudah ditentukan, maka program Design Expert 11.0 akan memberikan sejumlah prediksi formula optimum. Setiap prediksi formula optimum memiliki desirability. Nilai desirability memiliki kisaran $0-1$, semakin mendekati angka 1 artinya formula tersebut yang mendekati kondisi yang ditargetkan. Berdasarkan hasil optimasi RSM pada penelitian ini, diperoleh sebanyak sepuluh prediksi formula dengan respon viskositas dan nilai desirability tertinggi. Prediksi formula tersebut kemudian divalidasi dengan pembuatan ulang formula yang disarankan atau diprediksi dan dilakukan pengukuran respon hingga dihasilkan nilai yang aktual. Nilai respon aktual tersebut dibandingkan dengan nilai respon prediksi yang dikeluarkan oleh program Design Expert 11.0 sebelumnya. Validasi dilakukan untuk memberikan bukti bahwa tahapan proses yang dilakukan benar-benar menghasilkan nilai respon yang masuk dalam kisaran nilai yang ditentukan dan model percobaan sudah mencukupi untuk memprediksi kondisi optimal. Hasil validasi dalam perbandingan nilai respon viskositas spreadable gel biji selasih level prediksi dengan level aktual diperlihatkan dalam Tabel 4.

Dua dari sepuluh prediksi formula optimum dilanjutkan untuk penelitian tahap 3 (ditunjukkan dengan tanda $*$ pada Tabel 3 ). Pemilihan formula optimum untuk penelitian tahap 3 didasarkan pada tingkat desirability yang paling mendekati nilai 1.0 serta viskositas paling tinggi yaitu pada formulasi eksperimental 1 (viskositas $25100 \mathrm{cP}$, desirability 0,998) dan formulasi eksperimental 2 (viskositas 24000 cP, desirability 0,986).

\section{Formulasi Akhir Spreadable Gel Biji Selasih}

Formulasi akhir spreadable gel biji selasih dibuat menggunakan formula optimum yang terpilih dari tahap sebelumnya dan diberi penambahan perisa pada berbagai konsentrasi. Perisa yang dipilih adalah perisa leci dan jeruk agar sesuai dengan tampilan fisik dari spreadable gel biji selasih yang tanpa pemberian pewarna makanan. Formulasi akhir spreadable gel biji selasih pada tahap 3 diperlihatkan pada Tabel 5. 


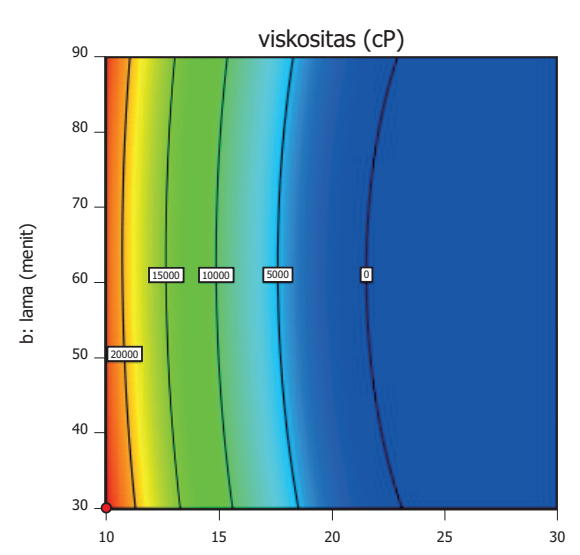

(a)

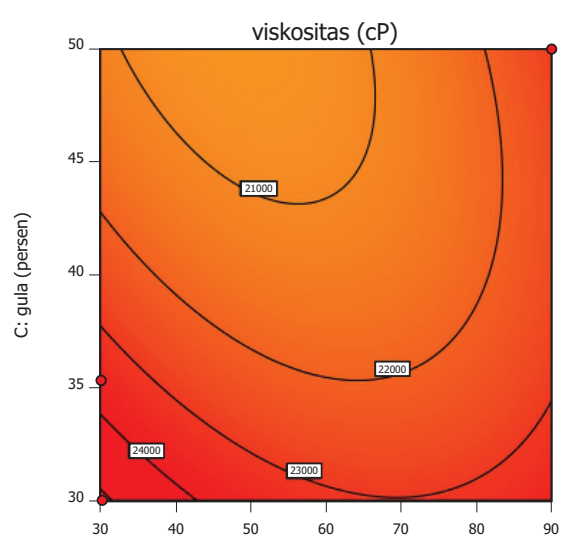

(d)

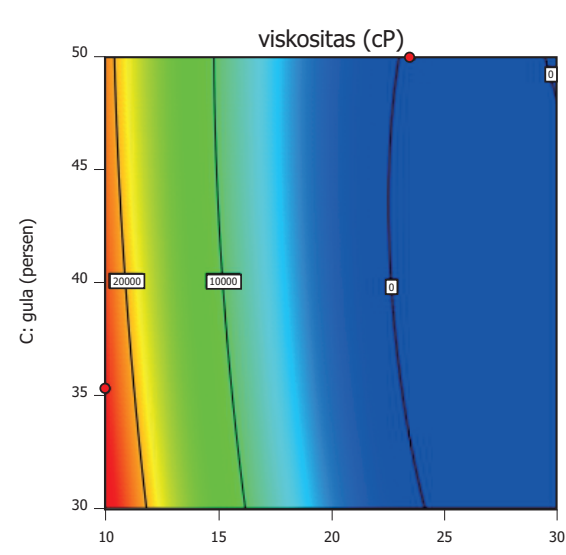

(b)

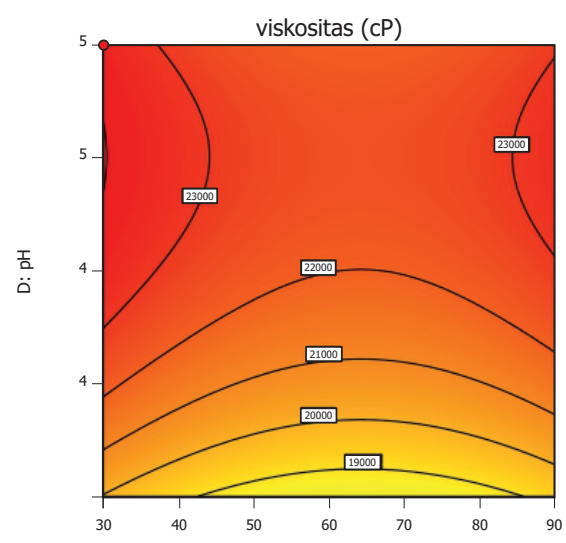

(e)

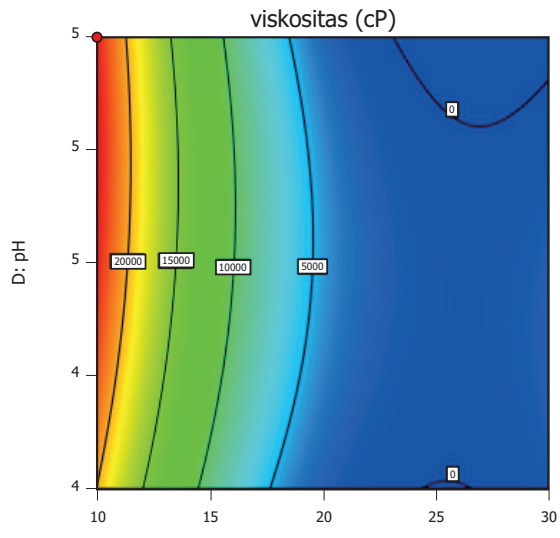

(c)

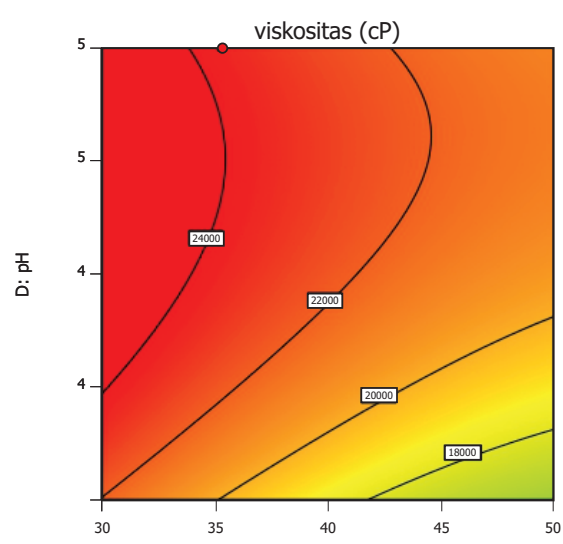

(f)

Gambar 1. Kontur RSM pengaruh interaksi berbagai variabel terhadap nilai respon viskositas spreadable gel biji selasih. Rasio biji selasih kering : air dengan lama perendaman (a), rasio biji selasih kering:air dengan penambahan gula (b), rasio biji selasih kering:air dengan rentang $\mathrm{pH}(\mathrm{c})$, lama perendaman dengan penambahan gula (d), lama perendaman dengan rentang $\mathrm{pH}(\mathrm{e})$, penambahan gula dengan rentang $\mathrm{pH}(\mathrm{f})$

Dua belas sampel produk dengan formulasi seperti pada Tabel 4 kemudian dilakukan analisis kimia meliputi total padatan terlarut ( ${ }^{\circ}$ Brix $)$, water activity $\left(\mathrm{a}_{\mathrm{w}}\right)$, sineresis, viskositas dan $\mathrm{pH}$. Analisis kimia produk tersebut bertujuan untuk memperoleh informasi komposisi kimia pada spreadable gel biji selasih (Tabel 6).

Setelah dilakukan analisis kimia pada dua belas formulasi spreadable gel biji selasih kemudian dilakukan pengerucutan tiga formulasi berdasarkan nilai respon viskositas yang paling tinggi yaitu formula 1 (F1) dengan nilai viskositas $24350 \mathrm{cp}$, formula 8 (F8) dengan nilai viskositas $24670 \mathrm{cp}$, dan formula 9 (F9) dengan nilai viskositas $24800 \mathrm{cp}$. Ketiga produk tersebut dilakukan uji sensori hedonik oleh 38 panelis terhadap atribut rasa, daya oles, dan tingkat kesukaan keseluruhan produk. Hasil ANOVA uji sensori diperlihatkan pada Tabel 7.

Hasil yang diperoleh dari uji sensori adalah sampel F9 mendapatkan nilai sensori yang paling tinggi, yaitu nilai rasa sebesar 5,34 (skala kuat), nilai daya oles sebesar 5,10 (skala mudah), dan nilai tingkat kesukaan sebesar 6,39 (skala suka). Sampel F9 menggunakan formulasi rasio biji selasih kering terhadap air 1:10, penambahan gula 30\%, lama perendaman 48 menit, nilai $\mathrm{pH} 5$, dan menggunakan perisa jeruk $0,1 \%$. Secara keseluruhan penilaian panelis berdasarkan uji hedonik terhadap produk spreadable gel biji selasih menunjukkan hasil atribut rasa yang disukai, daya oles yang tepat mudah, dan sineresis rendah. Hal ini juga terlihat dari hasil ANOVA tingkat kesukaan rasa panelis yang signifikan. Penilaian sensori berdasarkan tingkat kesukaan oleh panelis adalah untuk melihat ketertarikan pada produk spreadable gel biji selasih. Tingkat kesukaan ini merupakan salah satu faktor dalam menentukan kualitas dan tingkat penerimaan konsumen terhadap suatu produk spreadable gel. Penentuan mutu suatu produk tergantung beberapa 
Tabel 4. Perbandingan hasil nilai prediksi dan nilai aktual pada respon viskositas spreadable gel biji selasih

\begin{tabular}{cccccccc}
\hline No & A & B & C & D & Nilai viskositas prediksi & Desirability & Nilai viskositas aktual \\
\hline 1 & $1: 10$ & 48 & 30 & 5 & 24200,0 & $0,998^{*}$ & 25100 \\
2 & $1: 10$ & 90 & 30 & 5 & 23929,5 & $0,986^{*}$ & 24000 \\
3 & $1: 10$ & 57 & 30 & 5 & 23779,8 & 0,980 & 22000 \\
4 & $1: 10$ & 81 & 30 & 5 & 23754,6 & 0,979 & 23800 \\
5 & $1: 10$ & 80 & 30 & 5 & 23747,1 & 0,979 & 23800 \\
6 & $1: 10$ & 90 & 33 & 5 & 23678,9 & 0,976 & 24000 \\
7 & $1: 10$ & 70 & 30 & 5 & 23590,0 & 0,972 & 23550 \\
8 & $1: 10$ & 30 & 46 & 5 & 21554,4 & 0,885 & 22000 \\
9 & $1: 10$ & 30 & 49 & 5 & 21228,1 & 0,871 & 21500 \\
10 & $1: 10$ & 30 & 50 & 4 & 20461,7 & 0,839 & 20000 \\
\hline
\end{tabular}

Keterangan: Rasio biji selasih kering $(\mathrm{g})$ : air $(\mathrm{mL})[\mathrm{A}]$, lama perendaman (menit) [B], rentang pH [D], penambahan gula (\%) $[\mathrm{C}], *$ [formula terpilih untuk penelitian tahap 3].

Tabel 5. Formulasi akhir spreadable gel biji selasih

\begin{tabular}{|c|c|c|c|c|c|c|c|c|c|c|c|c|}
\hline \multirow{4}{*}{ Bahan } & \multicolumn{12}{|c|}{ Formula } \\
\hline & \multicolumn{6}{|c|}{ \% Perisa leci } & \multicolumn{6}{|c|}{$\%$ Perisa jeruk } \\
\hline & \multicolumn{2}{|c|}{0.05} & \multicolumn{2}{|c|}{0.1} & \multicolumn{2}{|c|}{0.2} & \multicolumn{2}{|c|}{0.05} & \multicolumn{2}{|c|}{0.1} & \multicolumn{2}{|c|}{0.2} \\
\hline & $F 1$ & $F 2$ & F3 & F4 & F5 & F6 & F7 & F8 & $F 9$ & F10 & $F 11$ & $F 12$ \\
\hline Biji selasih kering & 10 & 10 & 10 & 10 & 10 & 10 & 10 & 10 & 10 & 10 & 10 & 10 \\
\hline Gula sukrosa & 30 & 30 & 30 & 30 & 30 & 30 & 30 & 30 & 30 & 30 & 30 & 30 \\
\hline $\mathrm{pH}$ & 5 & 5 & 5 & 5 & 5 & 5 & 5 & 5 & 5 & 5 & 5 & 5 \\
\hline Air & 100 & 100 & 100 & 100 & 100 & 100 & 100 & 100 & 100 & 100 & 100 & 100 \\
\hline Lama perendaman & 48 & 90 & 48 & 90 & 48 & 90 & 48 & 90 & 48 & 90 & 48 & 90 \\
\hline Suhu cooking & 80 & 80 & 80 & 80 & 80 & 80 & 80 & 80 & 80 & 80 & 80 & 80 \\
\hline
\end{tabular}

Tabel 6. Hasil analisis kimia produk spreadable gel biji selasih

\begin{tabular}{cccccc}
\hline Formula & Total padatan terlarut ( ${ }^{\circ}$ Brix $)$ & $\mathrm{a}_{\mathrm{w}}$ & Sineresis $(\%)$ & Viskositas (cP) & $\mathrm{pH}$ \\
\hline F1 & 65 & 0,801 & $3,19 \pm 0,03^{*}$ & $24350^{*}$ & 5,12 \\
F2 & 64 & 0,822 & $3,27 \pm 0,21$ & 24200 & 5,10 \\
F3 & 64 & 0,805 & $3,10 \pm 0,28$ & 24310 & 5,05 \\
F4 & 63 & 0,814 & $3,11 \pm 0,22$ & 24100 & 5,00 \\
F5 & 64 & 0,810 & $3,15 \pm 0,22$ & 24280 & 5,00 \\
F6 & 64 & 0,823 & $3,30 \pm 0,22$ & 24300 & 5,00 \\
F7 & 64 & 0,836 & $3,30 \pm 0,22$ & 24300 & 5,10 \\
F8 & 65 & 0,825 & $3,23 \pm 0,15^{*}$ & $24670^{*}$ & 5,12 \\
F9 & 64 & 0,815 & $3,13 \pm 0,27 *$ & $24800^{*}$ & 5,07 \\
F10 & 64 & 0,810 & $3,09 \pm 0,34$ & 24300 & 5,00 \\
F11 & 63 & 0,810 & $3,67 \pm 0,40$ & 23550 & 4,97 \\
F12 & 64 & 0,824 & $3,22 \pm 0,27$ & 24400 & 5,00 \\
\hline
\end{tabular}

Keterangan: Tanda (*) adalah formula yang terpilih untuk dilanjutkan uji sensori hedonik

Tabel 7. Hasil ANOVA uji sensori hedonik spreadable gel biji selasih

\begin{tabular}{cccc}
\hline Formula spreadable gel & Rasa & Daya oles & Tingkat kesukaan keseluruhan produk \\
\hline F1 & $4,78^{\mathrm{b}}$ & 4,94 & $5,81^{\mathrm{b}}$ \\
F8 & $4,73^{\mathrm{b}}$ & 4,89 & $5,89^{\mathrm{b}}$ \\
F9 & $5,34^{\mathrm{a}}$ & 5,10 & $6,39^{\mathrm{a}}$ \\
\hline
\end{tabular}

Keterangan: Hasil adalah nilai rerata; huruf yang sama di belakang angka pada kolom yang sama menunjukkan tidak berbeda nyata $(p \leq 0,05)$ 


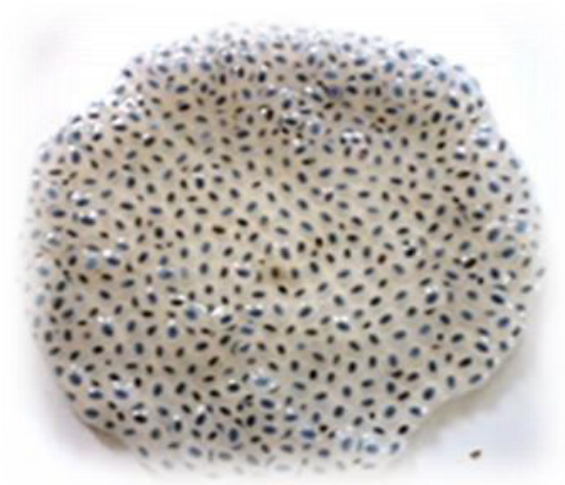

Gambar 2. Produk spreadable gel biji selasih

faktor, tetapi sebelum faktor lain diperhitungkan secara visual, faktor tingkat kesukaan terlebih dahulu menjadi hal yang menentukan mutu produk pangan. Rasa merupakan salah satu atribut yang sangat penting dalam produk pangan dan merupakan faktor penting dalam menentukan keputusan akhir konsumen untuk menerima atau menolak suatu produk pangan. Rasa merupakan tanggapan atas adanya rangsangan kimiawi yang sampai di indera pengecap, khususnya jenis rasa dasar yaitu manis, asam, asin dan pahit (Winarno, 2008). Hasil ANOVA yang signifikan pada atribut rasa karena adanya penambahan perisa jeruk yang dapat memberikan daya tarik panelis dan rasa enak mirip dengan karakteristik selai buah.

Analisis ANOVA pada daya oles tidak berpengaruh signifikan $(p>0.05)$, hal ini mungkin terjadi karena hidrokoloid pada biji selasih tidak memberikan bentuk kekentalan yang sama seperti pada produk selai yang telah ada dipasaran. Penambahan gula tidak berpengaruh signifikan pada pembuatan gel oles biji selasih sedangkan daya oles kemungkinan ada hubungannya dengan penambahan gula. Perlu diketahui bahwa penambahan gula akan menambah kekentalan sehingga meningkatkan viskositas. Selain itu nilai total padatan terlarut dan $\mathrm{pH}$ yang tidak berbeda jauh pada masing-masing formula (Tabel 6) juga menyebabkan daya oles tidak berpengaruh signifikan.

\section{KESIMPULAN}

Variasi rasio biji selasih kering:air, rentang $\mathrm{pH}$, dan penambahan gula dapat memberikan pengaruh terhadap karakteristik fisik gel biji selasih terutama nilai viskositasnya. Melalui metode Response Surface Methodology dapat diperoleh spreadable gel biji selasih terbaik dengan formulasi rasio biji selasih terhadap air $1: 10$, penambahan gula $30 \%$, lama perendaman 48 menit, dan $\mathrm{pH} 5$ dengan penambahan perisa jeruk 0,1\% yang menghasilkan nilai viskositas maksimum $24800 \mathrm{cP}$, tingkat sineresis $\pm 3 \%$ dan nilai sensori tingkat kesukaan pada angka rerata 6,39 skala suka.

\section{UCAPAN TERIMA KASIH}

Ucapan terima kasih penulis sampaikan kepada keluarga, rekan, dan dosen pembimbing yang membantu dalam penelitian ini.

\section{KONFLIK KEPENTINGAN}

Penulis menyatakan bahwa data dalam paper ini adalah asli dan belum pernah dipublikasikan, serta tidak ada konflik kepentingan.

\section{DAFTAR PUSTAKA}

AOAC: Official Methods of Analysis (Volume 1). (2005). 771.

Ayerza, R. (2011). The seed's oil content and fatty acid composition of chia (Salvia hispanica L.) var. Iztac 1, grown under six tropical ecosystems conditions. 36, 6.

Brodkorb, A., Egger, L., Alminger, M., Alvito, P., Assunção, R., Ballance, S., Bohn, T., Bourlieu-Lacanal, C., Boutrou, R., Carrière, F., Clemente, A., Corredig, M., Dupont, D., Dufour, C., Edwards, C., Golding, M., Karakaya, S., Kirkhus, B., Le Feunteun., Recio, I. (2019). INFOGEST static in vitro simulation of gastrointestinal food digestion. Nature Protocols. https://doi.org/10.1038/s41596-018-0119-1

Bucktowar, K., Bucktowar, M., \& Bholoa, L. D. (2016). A Review on Sweet Basil Seeds: Ocimum basilicum. World Journal of Pharmacy and Pharmaceutical Sciences, 5(12), 14.

Horwitz, W. \& AOAC International (Eds.). (2006). Official methods of analysis of AOAC International (18. ed., current through rev. 1, 2006). AOAC International.

Hosseini-Parvar, S. H., Matia-Merino, L., Goh, K. K. T., Razavi, S. M. A., \& Mortazavi, S. A. (2010). Steady shear flow behavior of gum extracted from Ocimum basilicum L. seed: Effect of concentration and temperature. Journal of Food Engineering, 101(3), 236-243. https://doi. org/10.1016/j.jfoodeng.2010.06.025

Mathews, S. (1993). Ocimum basilicum: A new nonconventional source of fibre. Food Chemistry, 47(4), 399401. https://doi.org/10.1016/0308-8146(93)90185-I

Meilgaard, M. C., Carr, B. T., \& Civille, G. V. (2007). Sensory Evaluation Techniques, Fourth Edition. 466.

Munir, M., Qayyum, A., Raza, S., Siddiqui, N. R., Mumtaz, A., Safdar, N., Shible, S., Afzal, S., \& Bashir, S. (2017). Nutritional Assessment of Basil Seed and its Utilization 
in Development of Value Added Beverage. Pakistan Journal of Agricultural Research, 30(3). https://doi. org/10.17582/journal.pjar/2017.30.3.266.271

Naji-Tabasi, S. \& Razavi, S. M. A. (2017). Functional properties and applications of basil seed gum: An overview. Food Hydrocolloids, 73, 313-325. https://doi.org/10.1016/j. foodhyd.2017.07.007

Nazir, S., Wani, I. A., \& Masoodi, F. A. (2017). Extraction optimization of mucilage from Basil (Ocimum basilicum L.) seeds using response surface methodology. Journal of Advanced Research, 8(3),235-244.https://doi. org/10.1016/j.jare.2017.01.003

Ramadhan, W. \& Trilaksani, W. (2017). Formulation of Hydrocolloid-Agar, Sucrose, and Acidulant on Jam Leather Product Development. Jurnal Pengolahan Hasil Perikanan Indonesia, 20(1), 95. https://doi. org/10.17844/jphpi.v20i1.16495

Razavi, S. M. A. (2017). Rheology and Texture of Basil Seed Gum: A New Hydrocolloid Source. 31. http://dx.doi. org/10.1016/B978-0-08-100431-9.00016-4

Razavi, Seyed M. A., Mortazavi, S. A., Matia-Merino, L., HosseiniParvar, S. H., Motamedzadegan, A., \& Khanipour, E. (2009). Optimisation study of gum extraction from Basil seeds (Ocimum basilicum L.). International Journal of Food Science \& Technology, 44(9), 1755-1762. https:// doi.org/10.1111/j.1365-2621.2009.01993.x

Salehi, F. \& Kashaninejad, M. (2018). The Effect of Thermal Treatments on the Rheological Behavior of Basil Seed
(Ocimum basilicum) and Balangu Seed (Lallemantia royleana) Gums. Journal of Food Biosciences and Technology, Islamic Azad University, Science and Research Branch, 8(1), 35-46

Samateh, M., Pottackal, N., Manafirasi, S., Vidyasagar, A., Maldarelli, C. \& John, G. (2018). Unravelling the secret of seed-based gels in water: The nanoscale 3D network formation. Scientific Reports, 8(1), 7315.https://doi. org/10.1038/s41598-018-25691-3

Segura-Campos, M. R., Ciau-Solís, N., Rosado-Rubio, G., ChelGuerrero, L., \& Betancur-Ancona, D. (2014). Chemical and Functional Properties of Chia Seed (Salvia hispanica L.) Gum. International Journal of Food Science, 2014, 1-5. https://doi.org/10.1155/2014/241053

Zameni, A., Kashaninejad, M., Aalami, M., \& Salehi, F. (2015). Effect of thermal and freezing treatments on rheological, textural and color properties of basil seed gum. Journal of Food Science and Technology, 52(9), 5914-5921. https://doi.org/10.1007/s13197-014-1679-x

Zhang, H., Li, Y., Wu, X., Zhang, Y., \&Zhang, D. (2010). Application of response surface methodology to the treatment landfill leachate in a three-dimensional electrochemical reactor. Waste Management, 30(11), 2096-2102. https://doi. org/10.1016/j.wasman.2010.04.029

Zhou, D. (2012). Seed Germination Performance and Mucilage Production of Sweet Basil (Ocimum basilicum L.). Journal of Virginia Polytechnic Institute and State University, $8(72), 12$. 